\title{
Local application of doxorubicin- loaded Iron oxid nanoparticles and the vascular disrupting agent via the hepatic artery: chemoembolization-photothermal ablation treatment of hepatocellular carcinoma in rats
}

Hongjun Yuan ${ }^{1}$, Xin Li ${ }^{1}$, Jing Tang ${ }^{1}$, Min Zhou ${ }^{2}$ and Fengyong Liu ${ }^{1 *}$

\begin{abstract}
Objectives: This study investigates the effectiveness of local application of doxorubicin(Dox)-loaded, polydopamine (PDA)- coated single crystal hematite $\left(\mathrm{a}-\mathrm{Fe}_{2} \mathrm{O}_{3}\right)$ nanocubes ( $\mathrm{Fe}_{2} \mathrm{O}_{3}-\mathrm{PDA}$-Dox) and combretastatin $\mathrm{A}-4$ phosphate disodium(CA4P)in treating hepatocellular carcinoma (HCC) in rats.

Methods: The magnetic characteristics and photothermal effects of the nanoparticles were determined in vitro. Tumor-bearing Sprague-Dawley rats were divided into 3 groups of 8 according to treatment: controls, transarterial chemoembolization-photothermal ablation (pTACE) (Lipidol+Fe $\left.\mathrm{O}_{3}-\mathrm{PDA}-\mathrm{Dox}+\mathrm{NIR}\right)$, and CA4P + pTACE (CA4P+ Lipidol $+\mathrm{Fe}_{2} \mathrm{O}_{3}-\mathrm{PDA}-\mathrm{Dox}+\mathrm{NIR}$ ). Drugs were administered through the hepatic artery, and the tumors exposed to 808-nm near-infrared radiation. The Fe content of tumors was assessed using neutron activation analysis. Treatment effectiveness was assessed using heating curves, magnetic resonance imaging, pathology results, and immunohistochemical analysis.

Results: The mean tumor Fe content was greater in rats treated with CA4P + pTACE $(1 \mathrm{~h}, 23.72 \pm 12.45 \mu \mathrm{g} / \mathrm{g} ; 24 \mathrm{~h}$, $14.61 \pm 8.23 \mu \mathrm{g} / \mathrm{g})$ than in those treated with PTACE alone $(1 \mathrm{~h}, 5.66 \pm 4.29 \mu \mathrm{g} / \mathrm{g} ; 24 \mathrm{~h}, 2.76 \pm 1.33 \mu \mathrm{g} / \mathrm{g})$. The tumor T2 imaging signal was lower in rats treated with CA4P + pTACE. Following laser irradiation, the tumor temperature increased, with higher temperatures reached in the CA4P + PTACE group $\left(62^{\circ} \mathrm{C}\right.$ vs $\left.55^{\circ} \mathrm{C}\right)$. Tumor cells exhibited necrosis, apoptosis, and proliferation inhibition, with greater effects in the CA4P + pTACE group. Transient liver and kidney toxicity were observed on day 3, with more severe effects after CA4P + pTACE.
\end{abstract}

Conclusions: $\mathrm{Fe}_{2} \mathrm{O}_{3}-\mathrm{PDA}-\mathrm{Dox}$ nanoparticles are effective for TACE-PTA. Pretreatment with CA4P increases nanoparticle uptake by tumors, increasing the treatment effectiveness without increasing hepatorenal toxicity.

Keywords: Iron oxide nanocomposites, Chemoembolization, Photothermal ablation, Hepatocellular carcinoma, CA4P

\footnotetext{
* Correspondence: liufengyong301@163.com

'Department of Interventional Radiology, The First Medical Center of PLA

General Hospital, Beijing 100853, China

Full list of author information is available at the end of the article
}

(c) The Author(s). 2019 Open Access This article is distributed under the terms of the Creative Commons Attribution 4.0 International License (http://creativecommons.org/licenses/by/4.0/), which permits unrestricted use, distribution, and reproduction in any medium, provided you give appropriate credit to the original author(s) and the source, provide a link to the Creative Commons license, and indicate if changes were made. The Creative Commons Public Domain Dedication waiver (http://creativecommons.org/publicdomain/zero/1.0/) applies to the data made available in this article, unless otherwise stated. 


\section{Introduction}

While transcatheter arterial chemoembolization (TACE) is an important method for treating intermediate and advanced stage HCC [1], tumor necrosis after TACE treatment is not complete, and recanalization of remnant tumor vessels is currently a major clinical concern [1-4]. Recent developments in nanotechnology have attracted great interest in the use of nano-scale photothermal materials in conjunction with chemotherapeutic drugs for the treatment of tumors [5]. $\mathrm{Fe}_{2} \mathrm{O}_{3}$ has been approved by the US Food and Drug Administration for use as a metal nanomaterial [6] for such purposes. This paramagnetic material can significantly shorten the magnetic resonance imaging (MRI) lateral relaxation time, has a characteristic low signal in T2 imaging, can be used as a T2 negative-contrast agent [7], and allows for monitoring of nanoparticle distribution within the body. Polydopamine (PDA), a biopolymer commonly used for drug delivery, can be linked to the chemotherapeutic agent doxorubicin (Dox). In the acidic microenvironment of a tumor, the $\mathrm{pH}$ sensitivity of PDA results in its release of Dox to the target site [8]. PDA exerts further tumoricidal effects through photothermal ablation (PTA) in response to near-infrared radiation (NIR) at a wavelength of $808 \mathrm{~nm}$ [9-11]. We designed an $\mathrm{Fe}_{2} \mathrm{O}_{3}$-PDA-Dox nanoparticle system capable of releasing Dox under low-pH conditions and facilitating T2 MRI imaging.

This study investigates the effects of the $\mathrm{Fe}_{2} \mathrm{O}_{3}$-PDADox nanoparticle system in combination with combretastatin A4-phosphate (CA4P), a vascular disrupting agent, on $\mathrm{HCC}$ in rats. We included CA4P in the treatment because it specifically blocks and destroys vessels supplying blood to tumors, inhibits the formation of new blood vessels, and increases the permeability of blood vessels and cell membranes [12, 13]. We believed that this approach to treatment could maximize the accumulation of chemotherapeutic drugs in the tumor locale, reduce toxic side effects, and achieve synergistic PTA and chemoembolization in the treatment of HCC. After injecting nanoparticles through the hepatic artery, treatment effectiveness with and without pretreatment with CA4P was assessed using Fe distribution analysis, heating curves, imaging, pathology results, and immunohistochemical analysis.

\section{Materials and methods}

\section{In vitro experiments}

\section{$\mathrm{Fe}_{2} \mathrm{O}_{3}-\mathrm{PDA}$ synthesis and Dox loading}

The microwave hydrothermal $(\mathrm{MH})$ method was used to synthesize ferric oxide nanocrystals [14] $\mathrm{Fe}_{2} \mathrm{O}_{3}$ nanoparticles $(100 \mathrm{mg})$ were dissolved in $100 \mathrm{~mL}$ Tris- $\mathrm{HCl}$ buffer

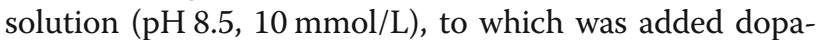
mine hydrochloride $(25 \mathrm{mg})$. The solution was mixed in the dark for $8 \mathrm{~h}$ and then centrifuged to obtain $\mathrm{Fe}_{2} \mathrm{O}_{3}$ nanoparticles modified with PDA $\left(\mathrm{Fe}_{2} \mathrm{O}_{3}\right.$ - PDA). $\mathrm{Fe}_{2} \mathrm{O}_{3}$ PDA nanocrystals $(100 \mathrm{mg})$ were added to an aqueous solution of Dox $(1 \mathrm{mg} / \mathrm{mL}, 40 \mathrm{~mL})$ at room temperature. The solution was mixed overnight in the dark and then centrifuged to collect the $\mathrm{Fe}_{2} \mathrm{O}_{3}$-PDA nanoparticles carrying dox.

\section{Release of Dox by $\mathrm{Fe}_{2} \mathrm{O}_{3}$-PDA-Dox nanoparticles}

$\mathrm{Fe}_{2} \mathrm{O}_{3}$-PDA-Dox $(25 \mathrm{mg}$ ) was added to $10 \mathrm{~mL}$ phosphate buffer solution (PBS) at $\mathrm{pH}$ of either 7.4 or 6.5 , and the solutions were agitated at $37^{\circ} \mathrm{C}$ until homogeneous. Ultraviolet-visible spectrophotometry was employed at wavelengths under $478 \mathrm{~nm}$ to calculate the release of Dox molecules at the different $\mathrm{pH}$ values. Percentage release was calculated as (cumulative amount of Dox released each time)/(total amount of Dox carried by the $\mathrm{Fe}_{2} \mathrm{O}_{3}$-PDA nanoparticles) * 100\%.

\section{In vitro magnetic properties of $\mathrm{Fe}_{2} \mathrm{O}_{3}-\mathrm{PDA}$ - Dox nanoparticles}

Nanoparticle solutions of $0,6.25 \mu \mathrm{g} / \mathrm{mL}, 12.5 \mu \mathrm{g} / \mathrm{mL}$, $25 \mu \mathrm{g} / \mathrm{mL}, 50 \mu \mathrm{g} / \mathrm{mL}, 100 \mu \mathrm{g} / \mathrm{mL}$, and $200 \mu \mathrm{g} / \mathrm{mL}$ were added to 1.5 Eppendorf tubes, and T2WI images were obtained using a 3.0 T MRI scanner (scanning parameters: use of a wrist coil; slice thickness, $2.0 \mathrm{~mm}$; number of slices, 16).

\section{Photothermal effect of in vitro $\mathrm{Fe}_{2} \mathrm{O}_{3}-\mathrm{PDA}-\mathrm{Dox}$ nanoparticles}

A fiber optic-coupled near-infrared laser (MDL-H-808-5 W) was used in vitro as a laser light source to test the photothermal response of $\mathrm{Fe}_{2} \mathrm{O}_{3}$-PDA-Dox nanoparticles at 0 , $5 \mu \mathrm{g} / \mathrm{mL}, 10 \mu \mathrm{g} / \mathrm{mL}$, and $20 \mu \mathrm{g} / \mathrm{mL}$. After near-infrared irradiation with a wavelength of $808 \mathrm{~nm}$ and a power density of $2.0 \mathrm{~W} / \mathrm{cm}^{2}$ for $5 \mathrm{~min}$ at room temperature, a forwardlooking infrared (FLIR) camera was used to monitor temperature changes.

\section{In vivo animal experiments \\ Establishment of a rat model of hepatoma in situ}

Mca-rh7777 rat hepatoma cells from the American Type Culture Collection Center (CRL-1601) were provided by Shanghai Rongbai Biological Technology Co., Ltd. After revival and culture, $4 \times 10^{6}$ cells were suspended in PBS and slowly injected into the rat liver using a 1-mL syringe. After this procedure, the rats were given antibiotics and dexamethasone intramuscularly for 3 days. Tumors formed within one week. The tumor-bearing rats were randomly divided into three groups according to treatment: control, pTACE (Lipidol $+\mathrm{Fe}_{2} \mathrm{O}_{3}$-PDA-Dox + $\mathrm{NIR}$ ), and CA4P + pTACE (CA4P + Lipidol + $\mathrm{Fe}_{2} \mathrm{O}_{3}-$ PDA-Dox + NIR), with 8 rats in each group. 
Hepatic artery chemoembolization (retrograde intubation of the hepatic artery via the gastroduodenal artery)

A midline incision was made, and the stomach was exposed and turned over to locate the gastroduodenal artery. The hepatic artery was freed along the gastroduodenal artery. The gastroduodenal artery was punctured using a $24 \mathrm{G}$ venous cannula, and a 0.014 -in. micro-guide wire made in the laboratory was inserted into the sheath of the cannula. The guide wire was selectively pushed into the hepatic artery proper, and the cannula sheath was pushed into the hepatic artery along the guide wire. The guide wire was then pulled out, and a micro catheter was superselectively inserted into the hepatic artery. Each group was administered a different drug combination, with the pTACE group given $1 \mathrm{~mL}$ iodinate oil mixed with $1 \mathrm{~mL}$ of $\mathrm{Fe}_{2} \mathrm{O}_{3}$-PDA-Dox $(20 \mu \mathrm{g} / \mathrm{mL})$, with NIR of the tumor location performed $3 \mathrm{~h}$ after injection. The CA4P + pTACE group first was given $0.5 \mathrm{~mL} 0.1 \mathrm{mg} / \mathrm{mL}$ CA4P, followed by infusion with $1 \mathrm{~mL}$ iodinate oil mixed with $1 \mathrm{~mL}$ of $\mathrm{Fe}_{2} \mathrm{O}_{3}$-PDA-Dox $(20 \mu \mathrm{g} / \mathrm{mL})$, with NIR irradiation performed $3 \mathrm{~h}$ after injection.

\section{Photothermal ablation}

An MDL-H-808-5 W near-infrared laser (Changchun New Industries) was used for irradiation using NIR with a wavelength of $808 \mathrm{~nm}$. After selecting a fiber optic cable, irradiation was performed at a distance of $40 \mathrm{~cm}$ and output power of $5 \mathrm{~W}$ using a diaphragm with a diameter of $1.2 \mathrm{~cm}$ aimed at the tumor area. The optical power density in the tumor area was approximately $4.4 \mathrm{~W} / \mathrm{cm}^{2}$, and the irradiation time was $5 \mathrm{~min}$. Following irradiation, the rat abdomens were closed and sutured. To prevent infection, 300,000 units of postoperative penicillin sodium was administered to each rat for 3 days.

\section{Neutron activation analysis, MRI imaging, and assessment of hepatorenal function}

Fe content of tumor tissue and peripheral normal liver tissue was determined at $1 \mathrm{~h}$ and $24 \mathrm{~h}$ after injection using neutron activation analysis after injection. MRI examination of rats in all three groups was performed before surgery and at 3,7 , and 10 days after injection using the examination method described. Coronal and axial T2 fat suppression (FS) images were acquired before and after treatment. The longest diameter and transverse diameter of each tumor were measured. Blood $(1 \mathrm{~mL})$ for biochemical analysis was drawn from the rat tail vein before surgery and at 3, 7, and 14 days after injection, and the concentrations of alanine transaminase (ALT), aspartate transaminase (AST), total bilirubin (TBIL), and creatinine (CREA) were compared.

\section{Statistical analysis}

All quantitative data are expressed as mean \pm standard deviation (SD). Comparative analysis was carried out using SPSS 23.0. Groups were compared using the t-test, and multi-group comparisons employed one-way ANOVA. The testing standard was $\alpha=0.05$, and $P<0.05$ indicated a statistically significant difference. Graphpad Prism 7.0 software was employed for charting.

\section{Results}

Loading of Dox onto $\mathrm{Fe}_{2} \mathrm{O}_{3}$-PDA nanoparticles and $\mathrm{pH}$ triggered release

Ultraviolet-visible spectra (Fig. S1a) reveal that $\mathrm{Fe}_{2} \mathrm{O}_{3}$ PDA-Dox and Dox have similar characteristic peaks at approximately $478 \mathrm{~nm}$, indicating that the $\mathrm{Fe}_{2} \mathrm{O}_{3}$-PDA nanoparticles successfully carried the Dox molecules. The in vitro drug-release curves of $\mathrm{Fe}_{2} \mathrm{O}_{3}$-PDA-Dox (Fig. S1b) indicate that in a PBS solution of neutral $\mathrm{pH}$ (7.4), the $\mathrm{Fe}_{2} \mathrm{O}_{3}$-PDA-Dox nanoparticles released roughly $2.0 \%$ of their Dox within $10 \mathrm{~h}$ and $7.5 \%$ of their Dox within $28 \mathrm{~h}$; at a pH of 6.5 , simulating the acidic environment of tumor tissue, 29 and $32 \%$ of the Dox was released at $10 \mathrm{~h}$ and $28 \mathrm{~h}$, respectively.

\section{Magnetic properties of $\mathrm{Fe}_{2} \mathrm{O}_{3}$-PDA-Doxnanoparticles}

Concentration-dependent $(0-200 \mu \mathrm{g} / \mathrm{mL})$ signal attenuation (Fig. S2) was seen in T2WI images, indicating the feasibility of using MRI to monitor the in vivo treatment process and verifying the use of $\mathrm{Fe}_{2} \mathrm{O}_{3}$-PDA-Dox nanoparticles as a negative MRI contrast agent.

\section{Photothermal response of $\mathrm{Fe}_{2} \mathrm{O}_{3}$-PDA-Dox nanoparticles}

The nanoparticle temperature increased steadily with increasing in vitro irradiation time (Fig. S3a). The heating curve (Fig. S3b) shows that the temperature gradually increased as the $\mathrm{Fe}_{2} \mathrm{O}_{3}$-PDA-Dox concentration increased from 0 to $20 \mu \mathrm{g} / \mathrm{material}$. After irradiation for $300 \mathrm{~s}$., the temperature of pure water increased only $3.5^{\circ} \mathrm{C}$ (room temperature, $24.5^{\circ} \mathrm{C}$ ) but increased roughly $35^{\circ} \mathrm{C}$ at a nanoparticle concentration of $20 \mu \mathrm{g} / \mathrm{mL}$, which was the greatest temperature increase.

\section{In vivo MRI monitoring of $\mathrm{Fe}_{2} \mathrm{O}_{3}-\mathrm{PDA}-\mathrm{Dox}$ distribution}

T2 MRI images were acquired at $1 \mathrm{~h}$ and $24 \mathrm{~h}$ after injection following the injection of $\mathrm{Fe}_{2} \mathrm{O}_{3}$-PDA-Dox nanoparticles (after CA4P injection in some groups) via the hepatic artery. The in vivo $\mathrm{Fe}_{2} \mathrm{O}_{3}$-PDA-Dox content of the tumor was assessed (Fig. 1). T2 image signals from the tumor were even lower at $24 \mathrm{~h}$ than at $1 \mathrm{~h}$ in both groups, indicating that most of the $\mathrm{Fe}_{2} \mathrm{O}_{3}$-PDA-Dox had entered the tumor tissue. The T2 signal in the CA4P + pTACE group was lower than that of the pTACE group at both $1 \mathrm{~h}$ and $24 \mathrm{~h}$ after injection, which indicates that the relaxation time of the tumor tissue was shorter in 

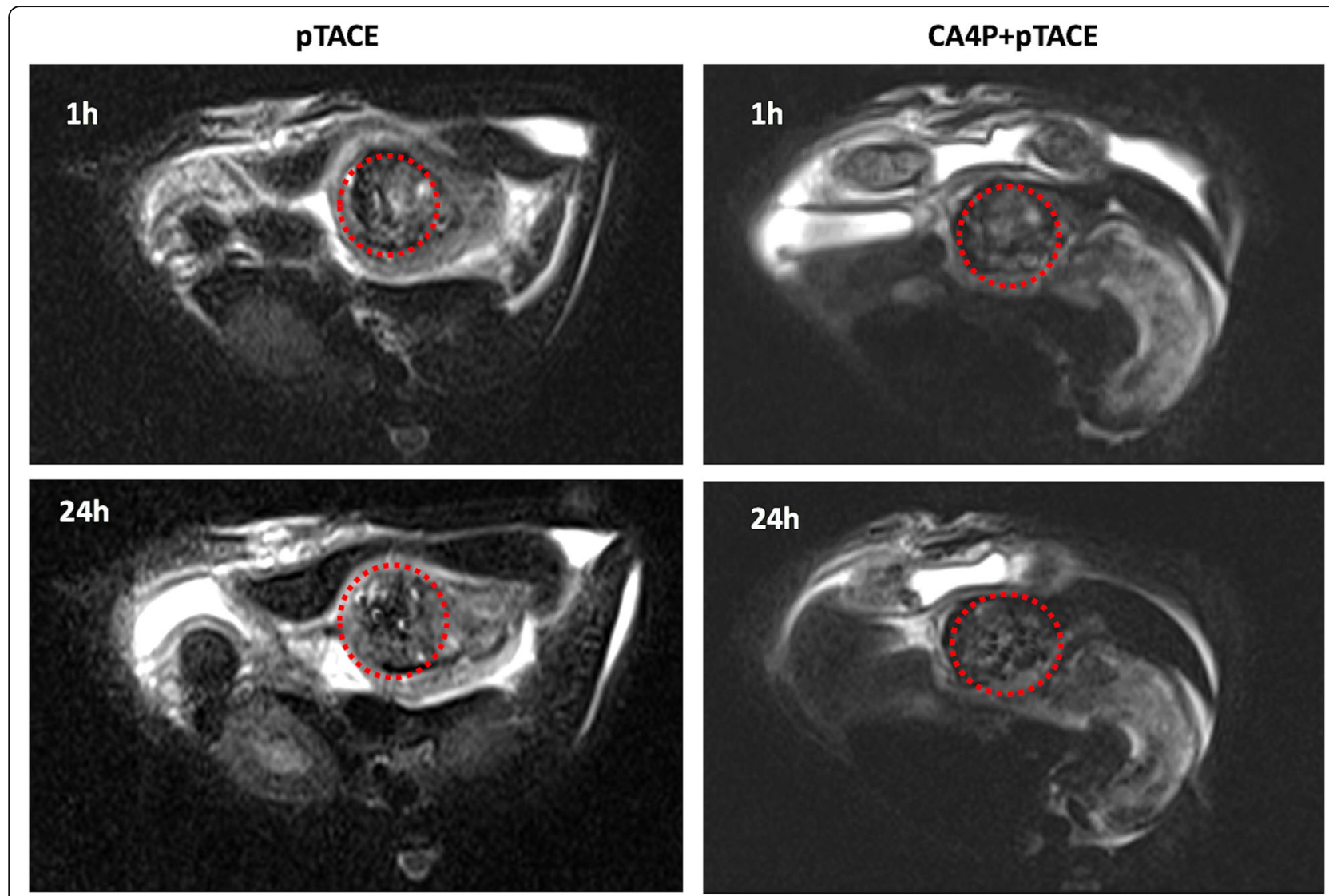

Fig. $1 \mathrm{~T} 2 \mathrm{Wl}$ imaging of rats in the pTACE and CA4P + pTACE groups at $1 \mathrm{~h}$ and $24 \mathrm{~h}$ after injection of $\mathrm{Fe}_{2} \mathrm{O}_{3}-\mathrm{PDA}-\mathrm{Dox}$. The rat hepatoma tissue is located within the red circle

the CA4P + pTACE group, and the tumor tissue in this group contained more $\mathrm{Fe}_{2} \mathrm{O}_{3}$-PDA-Dox particles. This observation indicates that CA4P promotes the uptake of $\mathrm{Fe}_{2} \mathrm{O}_{3}$-PDA-Dox by tumor tissue.

\section{Neutron activation analysis of tissue Fe content}

The mean Fe content of tumor tissue in the CA4P + pTACE group at $1 \mathrm{~h}$ and $24 \mathrm{~h}$ after injection was greater than that of normal liver tissue $(23.72 \pm 12.45 \mu \mathrm{g} / \mathrm{g}$ and $14.61 \pm 8.23 \mu \mathrm{g} / \mathrm{g}$; normal tissue, $4.66 \pm 1.52 \mu \mathrm{g} / \mathrm{g}$ and $7.67 \pm 1.35 \mu \mathrm{g} / \mathrm{g}$, respectively). The mean Fe content of tumor tissue in the pTACE group differed much less from that of normal tissue at $1 \mathrm{~h}$ and $24 \mathrm{~h}$ after injection $(5.66 \pm 4.29 \mu \mathrm{g} / \mathrm{g}$ and $2.76 \pm 1.33 \mu \mathrm{g} /$ g; normal liver, $3.53 \pm 1.23 \mu \mathrm{g} / \mathrm{g}$ and $8.58 \pm 2.64 \mu \mathrm{g} / \mathrm{g}$, respectively) (Fig. 2). This result indicates that while there was no significant difference in liver uptake of $\mathrm{Fe}_{2} \mathrm{O}_{3}$-PDA-Dox between these two groups, $\mathrm{Fe}_{2} \mathrm{O}_{3}$-PDA-Dox uptake was significantly higher in the in tumors treated with CA4P + pTACE than in those treated with pTACE alone.

\section{Photothermal ablation}

The temperature of the tumor area rose significantly in both groups following the injection of $\mathrm{Fe}_{2} \mathrm{O}_{3}$-PDA-Dox nanoparticles. In the pTACE group, the temperature increased to $42^{\circ} \mathrm{C}$ and $55^{\circ} \mathrm{C}$ at 1 and $5 \mathrm{~min}$ after near infrared laser irradiation, respectively. Greater temperature increases were observed in the CA4P + pTACE group, to $47^{\circ} \mathrm{C}$ and $62^{\circ} \mathrm{C}$ at 1 and $5 \mathrm{~min}$ after irradiation, respectively. The control group displayed a temperature increase of less than $5^{\circ} \mathrm{C}$ following irradiation. The resulting heating curve (Fig. 3 ) indicates that co-injection of CA4P promotes the uptake of $\mathrm{Fe}_{2} \mathrm{O}_{3}$-PDA nanoparticles by tumor tissue, with the temperature in the tumor area rising to over $60^{\circ} \mathrm{C}$ within $5 \mathrm{~min}$ after irradiation. This temperature can effectively kill tumor cells.

\section{MRI assessment of tumor treatment effectiveness}

MRI examination of liver tissue in the control, pTACE, and CA4P + pTACE groups was performed before and at $3 \mathrm{~d}, 7 \mathrm{~d}$, and $10 \mathrm{~d}$ after injection to dynamically assess tumor necrosis and changes in tumor volume (Fig. 4). On day 10, the tumor volume was $7.53 \pm 1.72 \mathrm{~cm}^{3}$ (control), $2.14 \pm 0.24 \mathrm{~cm}^{3}$ (pTACE), and $0.43 \pm 0.11 \mathrm{~cm}^{3}$ (CA4P + pTACE). The tumors in the control group grew steadily, and T2WI images displayed a slightly elevated signal. By comparison, the tumor volume was 


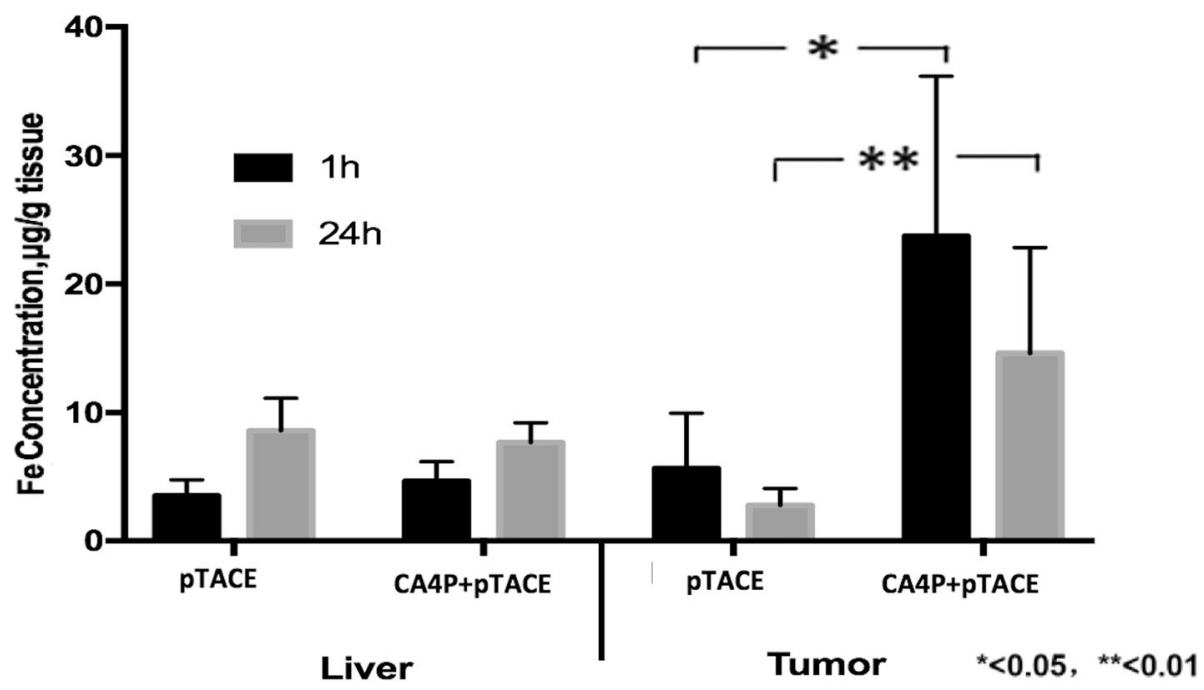

Fig. 2 Fe content of tumor tissue and liver tissue in rats treated with CA4P + pTACE and pTACE alone at $1 \mathrm{~h}$ and $24 \mathrm{~h}$ following injection of $\mathrm{Fe}_{2} \mathrm{O}_{3}-\mathrm{PDA}$-Dox

significantly lower in the pTACE and the CA4P + pTACE groups, and T2WI images displayed a slightly reduced signal. While the difference in volume change between the pTACE group and control group at $10 \mathrm{~d}$ was not significant, that between the CA4P + pTACE group and controls differed significantly.

\section{Pathology and immunohistochemistry results}

$\mathrm{H}$ \& E staining revealed that rats in the pTACE and CA4P + pTACE groups had small numbers of malformed, disarranged tumor cells, some of which appeared in the form of broad stripes. Necrosis was visible in most tissues, and infiltration by small numbers of inflammatory cells, as well as moderate amounts of fibrous tissue, were observed. Microscopic analysis of TUNEL- stained tissues revealed apoptosis in $26.27 \pm 5.65 \%$ of the tumor cells in the pTACE group and $31.58 \pm 6.82 \%$ of the tumor cells in the CA4P + pTACE group. Differences in the expression of tumor markers between the pTACE and CA4P + pTACE groups as indicated by immunohistochemical staining were as follows: Ki67, $0.75 \pm 0.67 \%$ vs $0.42 \pm 0.42 \%$; CD31 (MVD), $10.6 \pm 4.16 \%$ vs $8.40 \pm$ $4.01 \%$; VEGF, $148.63 \pm 42.48 \%$ vs $129.76 \pm 36.03 \%$, respectively. The low level of Ki-67 expression indicates significant tumor cell necrosis, apoptosis, and inhibition of proliferation in both groups after treatment. Angiogenesis was lower in tumors of animals treated with CA4P + pTACE than in those treated with pTACE alone, and the expression of CD31 and VEGF was qualitatively reduced accordingly (Fig. 5).

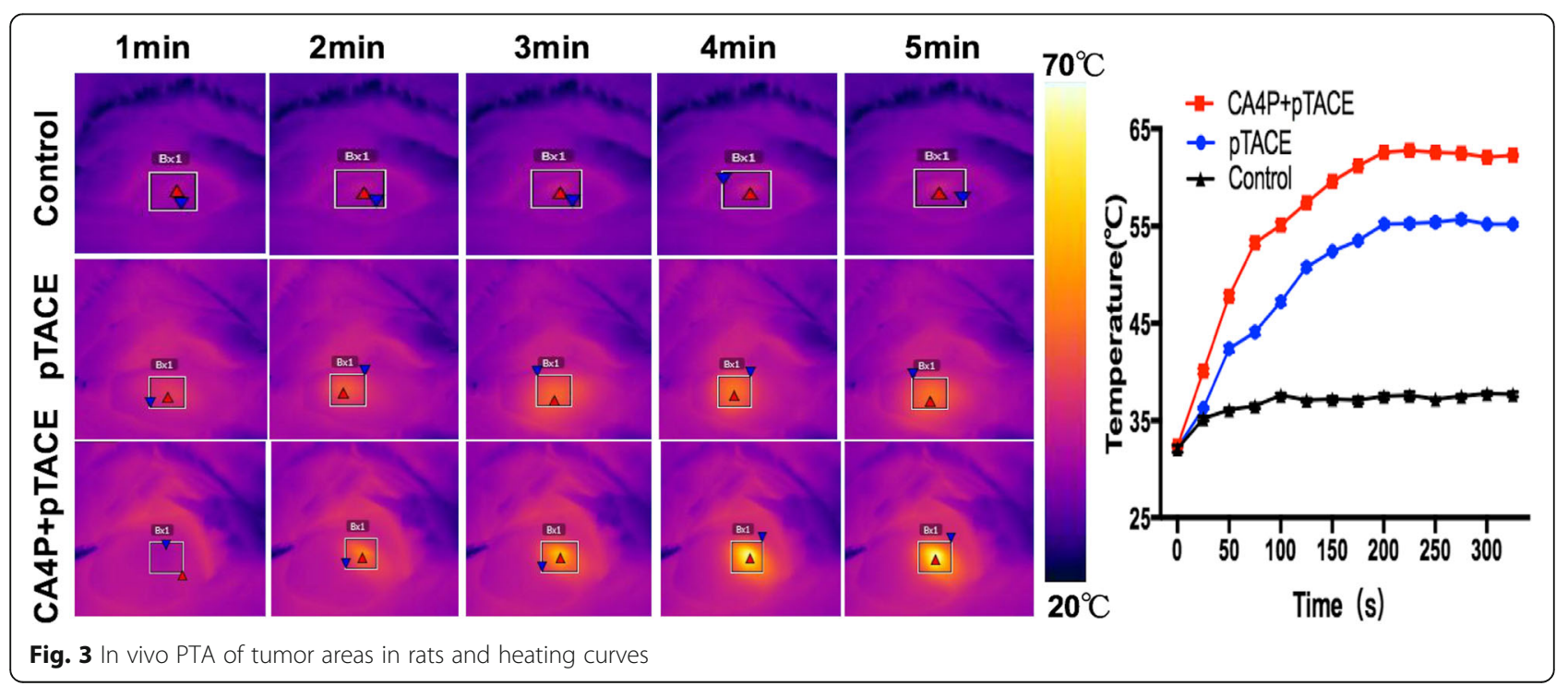




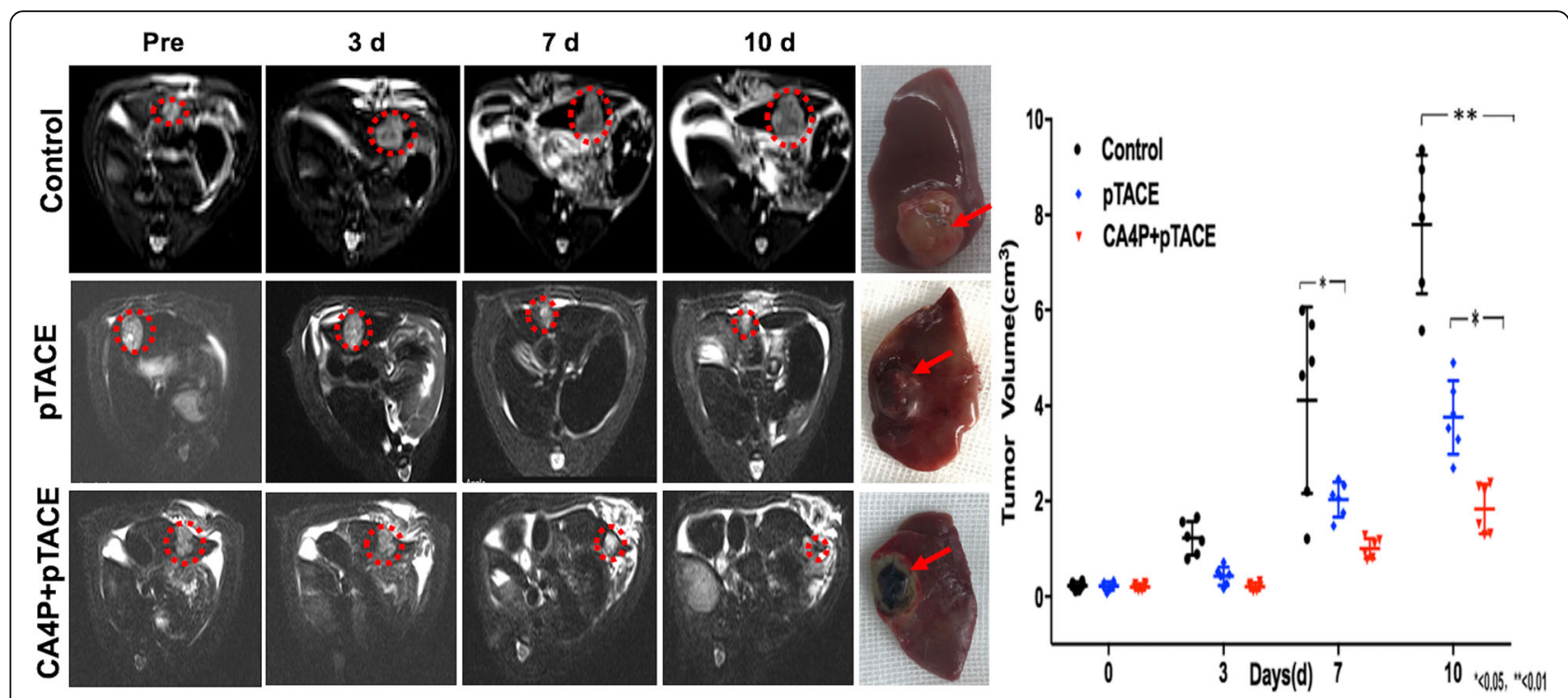

Fig. 4 In vivo MRI dynamic monitoring of tumor growth and volume changes in an in-situ rat hepatoma model following injection of $\mathrm{Fe}_{2} \mathrm{O}_{3}-$ PDA-Dox nanoparticles via the hepatic artery

\section{Safety: Hepatorenal toxicity}

Transient liver and kidney toxicity were observed in both groups on day 3 . The CA4P + pTACE group sustained more damage than did the pTACE group. The toxic effects gradually decreased on days 7 and 10. By day 10, the AST, ALT, and CREA levels were normal. Indicative of bile duct damage, TBIL levels increased slightly in both groups (Fig. 6), with no significant difference between the groups.

\section{Discussion}

Minimally invasive, interventional therapy is currently recognized as an important means of HCC $[15,16]$. New forms of interventional therapy have emerged with technological advances. Improvements in drug-carrying chemoembolization materials and noninvasive physical ablation methods would be of great clinical benefit [17, 18]. Of the many nano-biomaterials, multifunctional nanomaterials used in multimode imaging and chemoembolization-PTA (TACE-

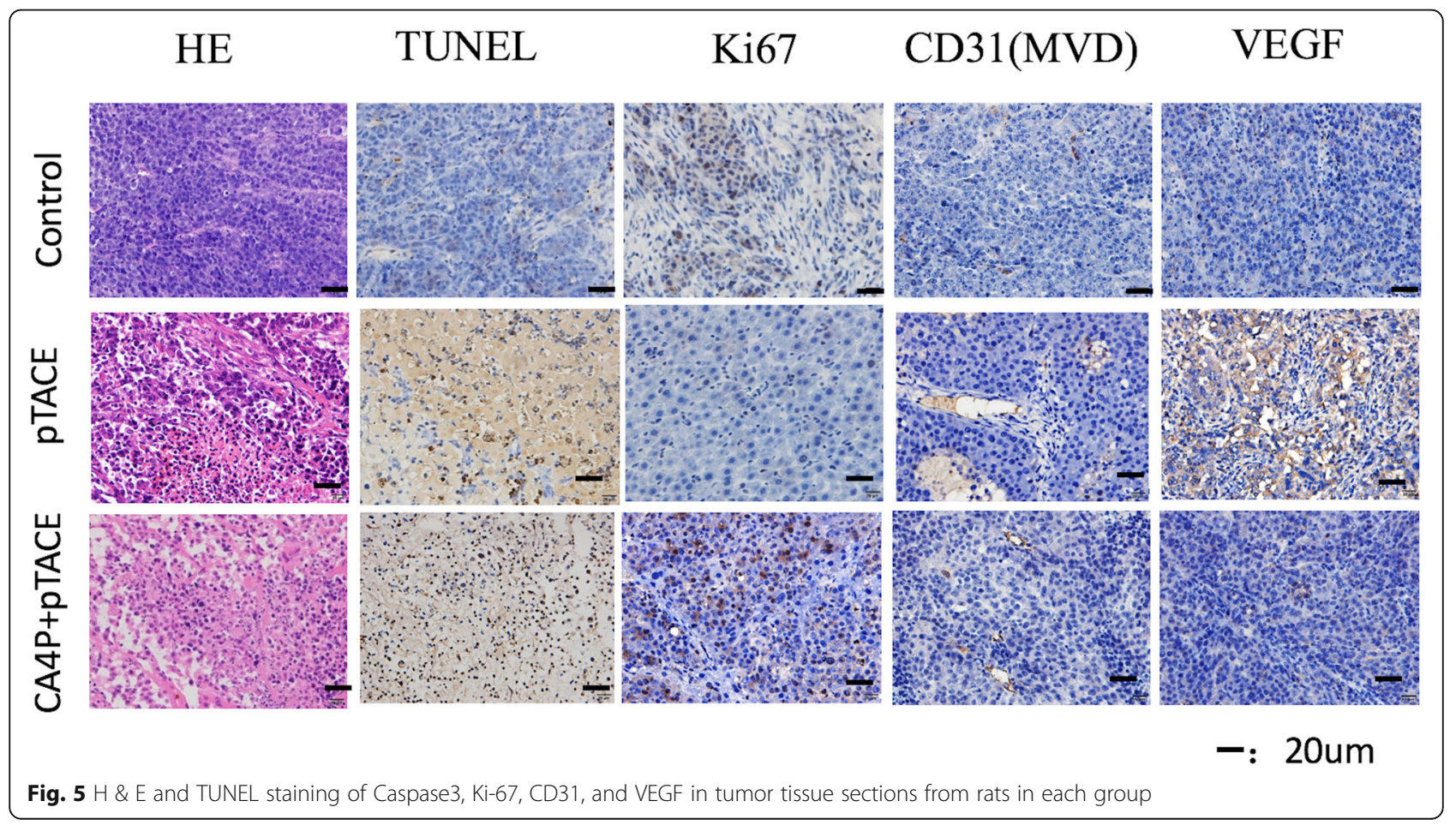



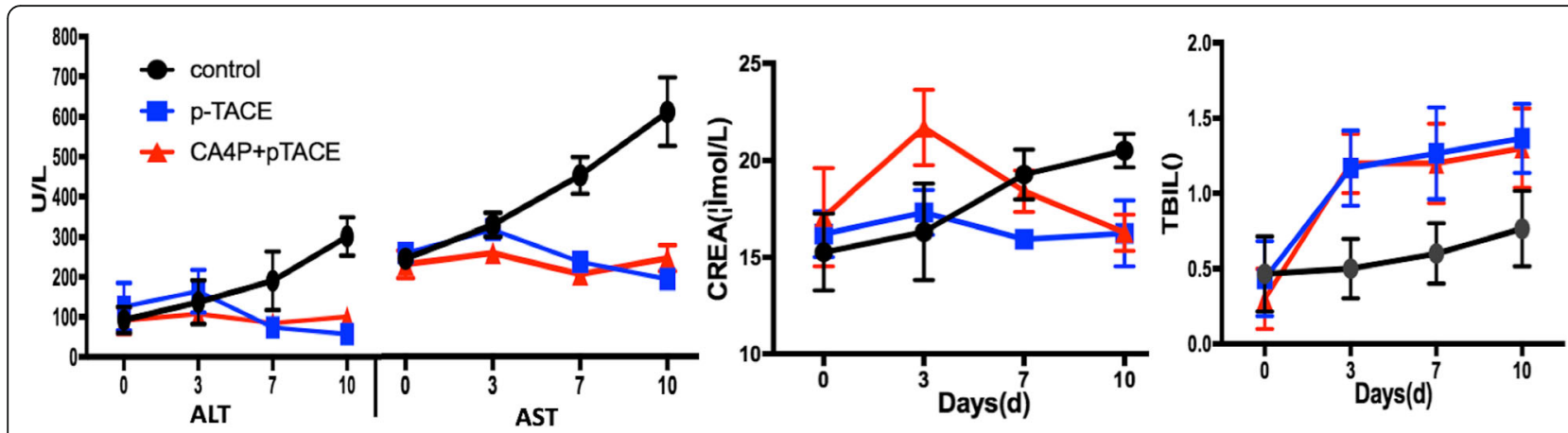

Fig. 6 Dynamic assessment of hepatorenal toxicity (ALT, AST, CREA, and TBIL) in the two groups during treatment

PTA) with imaging guidance [19] have attracted widespread attention, and the potential of multifunctional iron-based nanomaterials in clinical applications is particularly promising. We therefore designed and investigated the function of nanoparticles carrying $\mathrm{Fe}_{2} \mathrm{O}_{3}$-PDA-Dox for treating $\mathrm{HCC}$. Our results show that treatment with $\mathrm{CA} 4 \mathrm{P}$ improves the tumor uptake of nanoparticles carrying $\mathrm{Fe}_{2} \mathrm{O}_{3}$-PDA-Dox, increasing the effect of TACE and PTA to provide increased anti-tumor activity.

\section{$\mathrm{MRI}$, optical characteristics, and $\mathrm{pH}$-triggered release of nanoparticles carrying $\mathrm{Fe}_{2} \mathrm{O}_{3}$-PDA-Dox}

Because the iron in $\mathrm{Fe}_{2} \mathrm{O}_{3}$-PDA-Dox nanoparticles possesses superparamagnetism at room temperature, $\mathrm{Fe}_{2} \mathrm{O}_{3}$ PDA-Dox carrying nanoparticles will generate a strong local magnetic field in the presence of an external magnetic field, which strongly influences the relaxation of hydrogen protons in the water molecules around the particles. This effect shortens the T2 time of the hydrogen protons and causes T2 weighted images to appear dark $[7,20]$. We employed an in vitro experiment to further verify the ability of nanoparticles carrying $\mathrm{Fe}_{2} \mathrm{O}_{3}$ PDA to serve as negative contrast agents in MRI. Our results show that the T2 signal strength decreases with increasing concentrations of $\mathrm{Fe}_{2} \mathrm{O}_{3}$-PDA-Dox. PDA nanoparticles with a photothermal conversion function were first reported in 2013 by Liu et al. [21]. PDA possesses photothermal properties and offers relatively high photothermal conversion efficiency. As a consequence, we chose to use PDA as the primary photothermal material in the nanoparticles. $\mathrm{Fe}_{2} \mathrm{O}_{3}$-PDA-Dox nanoparticles have high absorbance in the near infrared zone and displays excellent in vitro heating when irradiated by NIR with a wavelength of $808 \mathrm{~nm}$ [9-11]. Monitoring of the solution temperature with a thermal imager verified the in vitro heating effect of $\mathrm{Fe}_{2} \mathrm{O}_{3}$-PDA-Dox nanoparticles following NIR, and in vivo results showed that the temperature of tumor tissue rose to $63.4{ }^{\circ} \mathrm{C}$ after irradiation for $5 \mathrm{~min}$, a temperature sufficient to kill tumor tissue [22, 23]. While the covalent bonds of
$\mathrm{Fe}_{2} \mathrm{O}_{3}$-PDA are highly effective at carrying dox [24], the $\mathrm{pH}$-sensitivity of PDA resulted in the release of Dox into simulated tumor tissue at $\mathrm{pH} 6.5$, with 29 and $32 \%$ of the Dox content released at 10 and $28 \mathrm{~h}$, respectively. Since the amount of drug released at $\mathrm{pH} 6.5$ was far greater than at $\mathrm{pH} 7.0$, this agent can be used for selective drug release during treatment. In summary, our results indicate that nanoparticles carrying $\mathrm{Fe}_{2} \mathrm{O}_{3}$-PDADox constitute a nano-scale drug-carrying system with the attributes of $\mathrm{pH}$-triggered drug release, capacity for MRI monitoring, photothermal responsiveness, and the ability to simultaneously achieve TACE and photothermal ablation effects.

Study on the use of CA4P in conjunction with $\mathrm{Fe}_{2} \mathrm{O}_{3}$-PDADox nanoparticles to treat HCC

The majority of HCC tumors are well supplied with blood from a variety of arteries [25]. As a consequence, necrosis is not complete following TACE treatment of some tumors $[4,25]$. The use of angiogenesis inhibitors targeting new blood vessels to increase the effectiveness of TACE has become an area of research interest [26, 27]. Binding of the active form of CA4P to the microtubule system of the vascular endothelium blocks angiogenesis, resulting in anti-tumor effects [28]. Głowacka et al. [29] verified that CA4P increases the permeability of endothelial cells by blocking the VE-cadherin/ $\beta$-catenin/Akt pathway, while simultaneously inhibiting the migration of endothelial cells and the formation of capillaries. This effect rapidly leads to vascular disruption and necrosis of tumor tissue. In view of the local nature of TACE and the characteristics of $\mathrm{CA} 4 \mathrm{P}$ and $\mathrm{Fe}_{2} \mathrm{O}_{3}$-PDA-Dox-carrying nanoparticles, we believed that CA4P could increase the permeability of tumor blood vessels, thereby increasing the uptake of $\mathrm{Fe}_{2} \mathrm{O}_{3}$-PDA-Dox nanoparticles by tumor tissue, resulting in increased effectiveness of TACE-photo-thermal ablation nanoparticles against tumors. A study by Wang et al. [30] suggests that a vascular disrupting agent is effective if administered $1-4 \mathrm{~h}$ before chemotherapy. Tozer et al. [31] reported that blood flow to tumors is reduced by $95 \%$ only 
$1 \mathrm{~h}$ after injection of CA4P, showing that extensive destruction of tumor capillaries occurs within $1 \mathrm{~h}$ of its administration. Using MRI monitoring of $\mathrm{Fe}_{2} \mathrm{O}_{3}$-PDA-Dox distribution, we observed that a decrease in the tumor T2 signal during the first $24 \mathrm{~h}$ after injection in the CA4P + pTACE group. $\mathrm{Fe}_{2} \mathrm{O}_{3}$-PDA-Dox particles accounted for most of this effect, and they became increasingly evenly distributed with time. Neutron activation analysis to measure Fe content revealed that while the uptake of $\mathrm{Fe}_{2} \mathrm{O}_{3}$ PDA by normal liver tissue did not differ significantly at 1 $\mathrm{h}$ and $24 \mathrm{~h}$, the uptake of $\mathrm{Fe}_{2} \mathrm{O}_{3}$-PDA-Dox at $1 \mathrm{~h}$ and $24 \mathrm{~h}$ in the CA4P + pTACE group was significantly greater than in the pTACE group. These results verified that preinjection of CA4P via the hepatic artery before TACE increases the uptake of nanoparticles by tumor tissue. Heating curves show that the temperature increase in tumors treated with TACE was greater in rats pre-treated with CA4P, indicating that CA4P increases the effectiveness of PTA. Dynamic MRI assessment of signal and volume changes after treatment revealed that the tumor T2 signal was lower in tumors of rats treated with CA4P + pTACE than in those treated with pTACE alone. This result shows that following PTA, necrosis was the most significant, shrinkage was the greatest, and treatment was most effective in those treated with CA4P + pTACE. Postoperative laboratory tests and immunohistochemical analyses indicated that the Ki-67 anti-angiogenesis effect following CA4P treatment was greater in tumors of rats treated with CA4P + pTACE than in those treated with pTACE alone. The expression of CD31 and VEGF qualitatively was lower in those treated with CA4P + pTACE, and hepatorenal toxicity did not differ between the groups. These findings show that CA4P increases the synergistic effectiveness of TACE photo-thermal ablation treatment.

\section{Conclusions}

Nanoparticles carrying $\mathrm{Fe}_{2} \mathrm{O}_{3}$-PDA-Dox as a new chemoembolization material allows for MRI-guided TACEPTA, with increased nanoparticle uptake provided by the pre-injection of CA4P via the hepatic artery. This procedure increases the relative concentration of $\mathrm{Fe}_{2} \mathrm{O}_{3}$-PDA-Dox in tumor tissues, thereby increasing the anti-tumor effects of TACE-PTA.

\section{Supplementary information}

Supplementary information accompanies this paper at https://doi.org/10. 1186/s40644-019-0257-x.

Additional file 1. The magnetic effect, photothermal effect and $\mathrm{PH}$ trigger release effect of the $\mathrm{Fe}_{2} \mathrm{O}_{3}$-PDA-Dox nanoparticles.

\section{Abbreviations}

CA4P: Combretastatin A-4 phosphate disodium: Dox: Doxorubicin; HCC: Hepatocellular carcinoma; INR: International normalized ratio;
PDA: Polydopamine; PTA: Photothermal ablation; TACE: Transarterial chemoembolization

\section{Acknowledgements}

This work was supported by the National Natural Science Foundation of China (No. 81671800); Beijing Municipal Natural Science Foundation (7172204);

Translational Medicine Project of PLA General Hospital(2017TM-013).

\section{Authors' contributions}

HY performed the data analyses and wrote the manuscript. FL and MZ contributed to the conception of the study. $X \mathrm{~L}$ and $Y G$ contributed significantly to analysis and manuscript preparation. All authors read and approved the final manuscript.

\section{Funding}

This study was supported by grants from The National Natural Science Foundation of China (No. 81671800), and The General Program of Beijing Municipal National Natural Science Foundation(No.7172204); Translational Medicine Project of PLA General Hospital(2017TM-013).

Availability of data and materials

Data sharing not applicable to this article as no datasets were generated.

\section{Ethics approval and consent to participate}

This study was conducted with the approval of the hospital review boards of the Chinese People's Liberation Army General Hospital and was performed according to the ethical standards laid down in the 1964 Declaration of Helsinki and its later amendments. Written informed consent was obtained from all of the patients for the TACE+RFA procedure. Additional informed consent was not required for this retrospective study.

\section{Consent for publication}

All study participants, or their legal guardian, written consent to publish individual person's data in the manuscript.

\section{Competing interests}

The Authors declare that they have no competing interests.

\section{Author details}

${ }^{1}$ Department of Interventional Radiology, The First Medical Center of PLA General Hospital, Beijing 100853, China. ${ }^{2}$ Institute of Translational Medicine, Zhejiang University, Hangzhou 310009, China.

Received: 8 July 2019 Accepted: 25 October 2019

Published online: 04 November 2019

\section{References}

1. Omata M, Cheng AL, Kokudo N, et al. Asia-Pacific clinical practice guidelines on the management of hepatocellular carcinoma: a 2017 update[J]. Hepatol Int. 2017;11(4):317-70.

2. Huo YR, Eslick GD. Transcatheter arterial chemoembolization plus radiotherapy compared with chemoembolization alone for hepatocellular carcinoma: a systematic review and meta-analysis[J]. Jama Oncology. 2015; 1(6):756.

3. Sergio A, Cristofori $C$, Cardin $\mathrm{R}$, et al. Transcatheter arterial chemoembolization (TACE) in hepatocellular carcinoma (HCC): the role of angiogenesis and invasiveness[J]. Am J Gastroenterol. 2008;103(4):914-21.

4. Farinati F, Giacomin A, Vanin V, et al. TACE treatment in hepatocellular carcinoma: what should we do now?[J]. J Hepatol. 2012:57(1):221-2.

5. Li H, Bian S, Huang Y, et al. High drug loading pH-sensitive pullulan-DOX conjugate nanoparticles for hepatic targeting[J]. J Biomed Mater Res A. 2013;102(1):150-9.

6. Taylor A, Wilson KM, Murray P, et al. Chemlnform abstract: long-term tracking of cells using inorganic nanoparticles as contrast agents: are we there yet?[J]. Chem Soc Rev. 2012;41(7):2707-17.

7. Dong L, Zhang P, Lei $P$, et al. PEGylated GdF3:Fe nanoparticles as multimodal T1/T2-weighted MRI and X-ray CT imaging contrast agents[J]. ACS Appl Mater Interfaces. 2017:9(24):20426-34

8. Masoudipour E, Kashanian S, Maleki N. A targeted drug delivery system based on dopamine functionalized nano graphene oxide[J]. Chem Phys Lett. 2017;668:56-63. 
9. Ruijun X. Bhirde, et al. hollow iron oxide nanoparticles as multidrug resistant drug delivery and imaging vehicles[]]. Nano Res. 2013;6(1):1-9.

10. López T, Quintana P, Martínez JM, et al. Stabilization of dopamine in nanosilica sol-gel matrix to be used as a controlled drug delivery system[]]. J Non-Cryst Solids. 2007;353(8-10):987-9.

11. Liu Y. Dopamine-melanin colloidal Nanospheres for MRI-guided Photothermal therapy[M]//multifunctional Nanoprobes. Singapore: Springer; 2018. p. 121-51.

12. Su J, Laursen BE, Eskildsen-Helmond Y, et al. The vascular-disrupting agent, combretastatin-A4-phosphate, enhances neurogenic vasoconstriction in rat small arteries[J]. Eur J Pharmacol. 2012;695(1-3):104-11.

13. Zhao D, Chang CH, Kim JG, et al. In vivo near-infrared spectroscopy and magnetic resonance imaging monitoring of tumor response to Combretastatin A-4-phosphate correlated with therapeutic outcome[J]. Int J Radiat Oncol Biol Phys. 2011;80(2):574-81.

14. Burda C, Chen X, Narayanan R, et al. Chemistry and properties of nanocrystals of different shapes[]]. Chem Rev. 2005;105(4):1025-102.

15. Molla $N$, Almenieir $N$, Simoneau $E$, et al. The role of interventional radiology in the management of hepatocellular carcinoma[J]. Current Oncology, 2014, 21(3):480-

16. Song DS, Nam SW, Si HB, et al. Outcome of transarterial chemoembolization-based multi-modal treatment in patients with unresectable hepatocellular carcinoma[J]. World J Gastroenterol. 2015;21(8): 2395-404.

17. Cai W, Gao H, Chu C, et al. Engineering photo-Theranostic Nanoscale metalorganic frameworks for multi-modal imaging-guided Cancer therapy[]]. ACS Appl Mater Interfaces. 2017;9(3):2040-51.

18. Zottis ADA, Beltrame JM, Lara LRS, et al. Pheomelanin-coated iron oxide magnetic nanoparticles: a promising candidate for negative T2 contrast enhancement in magnetic resonance imaging[J]. Chem Commun. 2015; 51(56):11194-7.

19. Li J, Zhou M, Liu F, et al. Hepatocellular Carcinoma: Intra-arterial Delivery of Doxorubicin-loaded Hollow Gold Nanospheres for Photothermal AblationChemoembolization Therapy in Rats.[J]. Radiology, 2016, $281(2): 152510$.

20. Yuan Y, Ding Z, Qian J, et al. Casp3/7-Instructed Intracellular Aggregation of Fe304 Nanoparticles Enhances T2 MR Imaging of Tumor Apoptosis[]]. Nano Lett. 2016:16(4).

21. Liu Y, Ai K, Liu J, et al. Dopamine-melanin colloidal nanospheres: an efficient near-infrared photothermal therapeutic agent for in vivo cancer therapy.[]]. Adv Mater. 2013;25(9):1353-9.

22. Targeted polydopamine nanoparticles enable photoacoustic imaging guided chemo-photothermal synergistic therapy of tumor[J]. Acta Biomater, 2017, 47:124-134,

23. Thakur S, Lavito S, Grobner E, et al. Radiofrequency thermal ablation heat energy transfer in an ex-vivo model[J]. Am Surg. 2017;83(12):1373-80.

24. Das P, Jana NR. Dopamine functionalized polymeric nanoparticle for targeted drug delivery[]]. RSC Adv. 2015;5(42):33586-94.

25. Yu SC, Yeung DT, So NM. Imaging features of hepatocellular carcinoma.[J]. Clin Radiol. 2004;59(2):145-56.

26. Berretta $\mathrm{M}$, Rinaldi $\mathrm{L}$, Di BF, et al. Angiogenesis inhibitors for the treatment of hepatocellular carcinoma[J]. Front Pharmacol. 2016;7.

27. Odisio BC, Kaseb AO. Anti-angiogenic therapy in the setting of TACE: an elusive synergy?[]]. Lancet Gastroenterology and Hepatology. 2018;3(1):5.

28. Su M, Huang J, Liu S, et al. The anti-angiogenic effect and novel mechanisms of action of Combretastatin A-4[]]. Sci Rep. 2016;6:28139.

29. Siebert A, Gensicka M, Cholewinski G, et al. Synthesis of combretastatin A-4 analogs and their biological activities[]]. Anti-Cancer Agents in Medicinal Chemistry (Formerly Current Medicinal Chemistry-Anti-Cancer Agents). 2016; 16(8):942-60.

30. Wang ES, Pili R, Seshadri M. Modulation of chemotherapeutic efficacy by vascular disrupting agents: optimizing the sequence and schedule.[J]. Journal of Clinical Oncology Official Journal of the American Society of Clinical Oncology. 2012;30(7):761-3.

31. Tozer GM, Prise VE, Wilson J, et al. Mechanisms associated with tumor vascular shut-down induced by combretastatin A-4 phosphate: intravital microscopy and measurement of vascular permeability[]]. Cancer Res. 2001; 61(17):6413-22.

\section{Publisher's Note}

Springer Nature remains neutral with regard to jurisdictional claims in published maps and institutional affiliations.

\section{Ready to submit your research? Choose BMC and benefit from:}

- fast, convenient online submission

- thorough peer review by experienced researchers in your field

- rapid publication on acceptance

- support for research data, including large and complex data types

- gold Open Access which fosters wider collaboration and increased citations

- maximum visibility for your research: over $100 \mathrm{M}$ website views per year

At $\mathrm{BMC}$, research is always in progress.

Learn more biomedcentral.com/submissions 